\title{
Testicular hypoplasia in a boar with abnormal sex chromosome constitution ( 39 XXY)
}

\author{
J. L. Hancock and M. G. Daker* \\ Department of Anatomy, Royal Veterinary College, Royal College Street, London NW1 OTU, \\ and *Paediatric Research Laboratory, Guy's Hospital Medical School, London SE1 9RT, U.K.
}

\begin{abstract}
Summary. A boar with testicular hypoplasia had 39 chromosomes. Giemsa banded preparations permitted unambiguous identification of an XXY sex chromosome constitution. Spermatogenic tissue was absent as in $\mathrm{X}$ chromatin-positive Klinefelter syndrome of man.
\end{abstract}

\section{Introduction}

Testicular hypoplasia associated with an abnormal sex chromosome constitution has been reported in several domestic species (see Bruère, 1974; Logue, Harvey, Munro \& Lennox, 1979). The essential features comprise a gross reduction in testicular size associated histologically with virtual absence of spermatogenic cells and with an additional X chromosome so that affected individuals have the constitution XXY. This paper records the identification of a boar with such a karyotype.

\section{Materials and Methods}

The animal was identified as having abnormally small testes at a routine examination towards the end of performance test at a Meat and Livestock Commission Pig Testing Station. Blood was collected from the jugular vein into heparinized bottles before slaughter at a commercial abattoir. Thin $(5 \mathrm{~mm})$ blocks were cut from the face of the halved unfixed testis and fixed in buffered formal-saline ( $\mathrm{pH} \mathrm{7.0)}$. Suspensions of epididymal contents were made by incising the cauda epididymidis and removing a few drops of material from the cut surface into $10 \mathrm{ml}$ buffered formal-saline. The fixed preparations and blood samples were despatched to London for processing and examination.

Lymphocyte cultures were set up and harvested according to standard procedures. Air-dried preparations were either G-banded using a modification of the trypsin method of Seabright (1971) or were stained in orcein. Banded karyotypes were prepared in accordance with the recommendations made by Ford, Pollock \& Gustavsson (1980).

The tissue blocks were embedded in methacrylate, sectioned at $2 \mu \mathrm{m}$ on a Sorval Porter Blum JB4 microtome and stained with haematoxylin and eosin.

Smears of epididymal contents were prepared from the fixed suspensions and stained with methyl violet borax. Further preparations were examined by phase-contrast microscopy. 


\section{Results}

The boar weighed $120 \mathrm{~kg}$ when slaughtered at 230 days of age; no detailed observations were made at autopsy.

No spermatozoa could be identified by microscopical examination of epididymal contents. The histological features of the testis (PI. 1, Fig. 1) conform to those associated with an XXY constitution in other species. The interstitial tissue is normal. There is a total absence of spermatogenic tissue, the tubules being lined exclusively by Sertoli cells.

The nuclei of the Sertoli cells can be seen to have a rather regular outline and to lack the invagination of the nuclear membrane which, although not prominent in boar Sertoli cells (in contrast, for example, to those of bull cells), are nevertheless a distinctive feature of the cells in normal adult tubular epithelium.

Table 1. The numbers of chromosomes from G-banded and orcein-stained preparations of lymphocytes from a boar with testicular hypoplasia

\begin{tabular}{lccccccc}
\hline & $\begin{array}{c}\text { Total no. of } \\
\text { cells } \\
\text { examined }\end{array}$ & & \multicolumn{4}{c}{ No. of chromosomes per cell } \\
\cline { 3 - 8 } & 95 & 36 & 37 & 38 & 39 \\
\hline G-banded & 9 & & & 1 & & 8 \\
Orcein-stained & 80 & 1 & 1 & 3 & 9 & 66 \\
\hline
\end{tabular}

The findings from the chromosomal studies are summarized in Table 1. Of a total of 80 cells examined in orcein-stained preparations, 66 had 39 chromosomes. Spreads with 38 or fewer chromosomes showed random loss and are considered to be technical artefacts. From analysis of G-banded spreads (Pl. 1, Fig. 2) the extra chromosome was identified as an X chromosome, which in pig, as in a number of other mammals including man and other higher primates, has a distinctive dark band in the middle of the short arm, and a similar band approximately the same distance from the centromere in the long arm. These results provide conclusive evidence of an XXY chromosome constitution.

\section{Discussion}

Two previous records exist of the identification of XXY cell lines in adult pigs. Breeuwsma (1968) recorded the identification of a Danish Landrace pig with an XXY karyotype. This animal was described as an intersex. Histological examination of the testes showed no spermatogenic activity. Of 32 cells examined, 30 were found to have 39 chromosomes; sex chromatin was demonstrated in $90 \%$ of an unspecified number of neurones, providing indirect evidence of a cell line with two $\mathrm{X}$ chromosomes. The assumption that the extra chromosome was an $\mathrm{X}$ chromosome is reasonable but no evidence could be given in support of the assumption such as is now available from the application of more recently developed banding methods. Harvey (1968) recorded findings which were interpreted as evidence of the existence of XXY/XXXY mosaicism in a pig with testicular hypoplasia. The evidence for the XXY cell line

\section{PLATE 1}

Fig. 1. Methacrylate section of hypoplastic boar testis showing tubules lined by Sertoli cells. No spermatogenic cells are identifiable. Interstitial tissue is normal. $\times 315$.

Fig. 2. Karyotype of boar showing abnormal (XXY) sex chromosome constitution. Giemsabanded preparation. $\times 1750$. 
PLATE 1

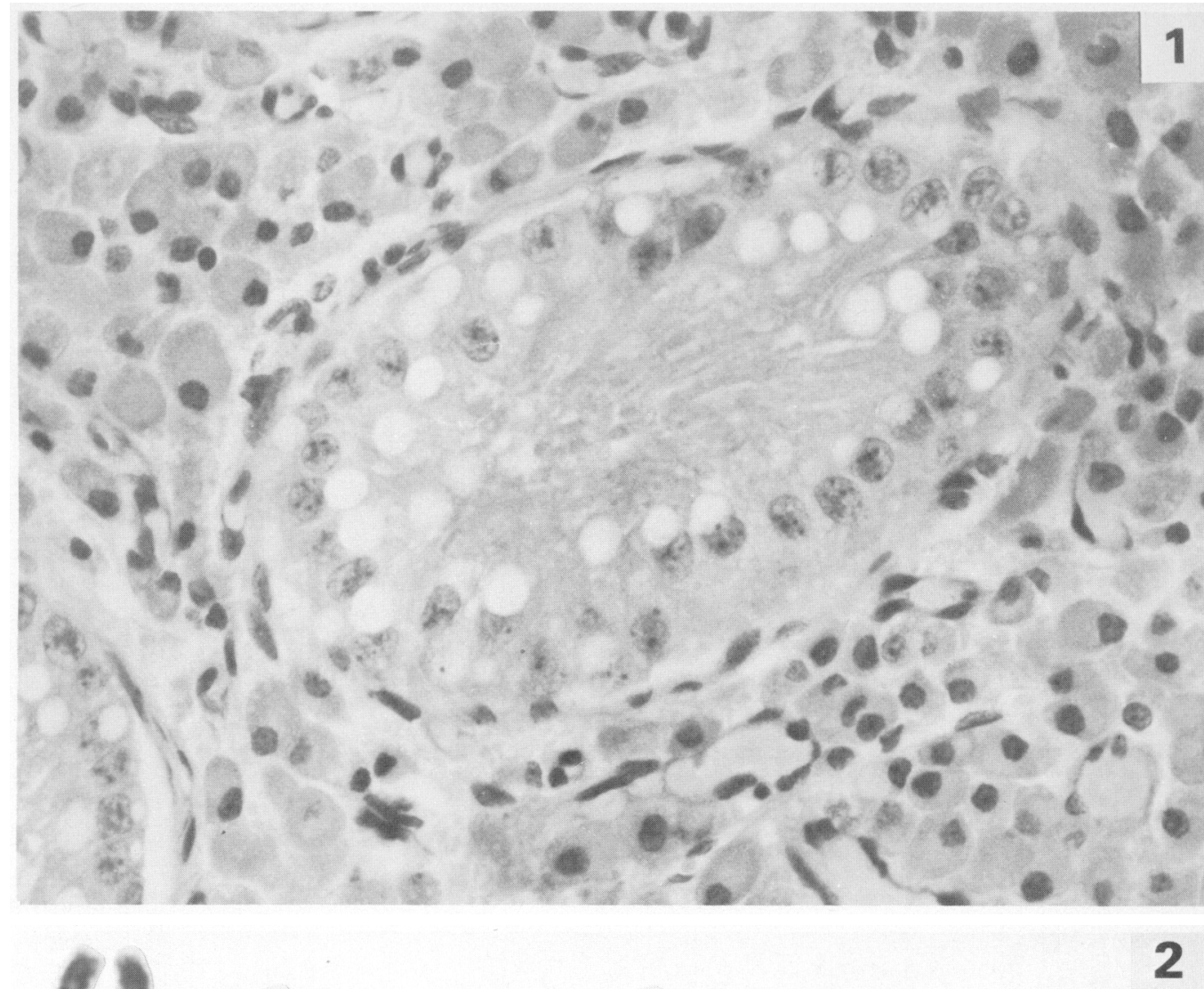

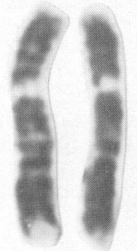

1

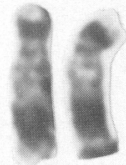

6

î

8

(2) 유

13

14

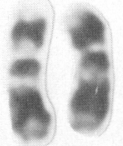

2

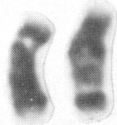

7 it

3

2

4

5

1

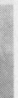
$x^{-12}+x^{-1}$ 
was based on examination of 172 cells from orcein-stained preparations, 120 being observed to have 39 chromosomes. Analyses from photomicrographs showed the extra chromosome to be indistinguishable from the $\mathrm{X}$ chromosome in 15 out of 17 of these cells. The evidence for the XXXY cell line was apparently based on the finding of 30 cells with 40 chromosomes, and on analysis of sex (X) chromatin. Only 2 of the 40 chromosome cells were suitable for detailed analysis and "these showed no constant picture", but it is recorded that 9 out of 150 interphase nuclei examined showed 2 sex (X) chromatin masses, which would support the possibility of an XXXY minor cell line.

We believe that the findings recorded here provide for the first time unambiguous evidence of the existence of a condition directly comparable with the $\mathrm{X}$ chromatin-positive Klinefelter syndrome of man (Klinefelter, Reifenstein \& Albright, 1942; Jacobs \& Strong, 1959).

We thank Mr R. P. Anderson, M.R.c.v.s. for taking blood and tissue samples, Miss V. M. McGuire for culture procedures, $\mathrm{Mr} \mathrm{H}$. A. Burgess and Mr J. B. Edwards for histological and photographic assistance; and Dr D. R. Melrose, Head of Veterinary Services, Meat and Livestock Commission, for facilities.

\section{References}

Breeuwsma, A J. (1968) A case of sex chromosome constitution in an intersex pig. J. Reprod. Fert. 16, 119-120.

Bruère, A.N. (1974) The discovery and biological consequences of some important chromosome anomalies in populations of domestic animals. Proc. Ist Wld Congr. Genet. appl. Livestock Prod., Madrid, pp. 151-175. Graficas Orbe, S.L. Paddilla, 82 Madrid.

Ford, C.E., Pollock, D.L. \& Gustavsson, I. (Eds) (1980) Proceedings of the First International Conference for the Standardisation of Banded Karyotypes of Domestic Animals. University of Reading, England, 1976. Hereditas 92, 145-162.

Harvey, M.J.A. (1968) A male pig with an XXY/XXXY sex chromosome complement. J. Reprod. Fert. 17, 319-324.

Jacobs, P.A. \& Strong, J.A. (1959) A case of human intersexuality having a possible XXY sexdetermining mechanism. Nature, Lond. 183, 302303.

Klinefelter, H.F., Jr, Reifenstein, E.C., Jr \& Albright, F. (1942) Gynecomastia, aspermatogenesis without a Leydigism and increased excretion of follicle-stimulating hormone. J. clin. Endocr. Metab. 2, 615-627.

Logue, D.N., Harvey, M.J.A., Munro, C.D. \& Lennox, B. (1979) Hormonal and histological studies in a 61 XXY bull. Vet. Rec. 104, 500-503.

Seabright, M. (1971) A rapid banding technique for human chromosomes. Lancet ii, 971-972.

Received 19 May 1980 